\title{
Diachronic analysis of farmers' strategies within a protected area of central Italy
}

\author{
Nicola Silvestri, ${ }^{1}$ Chiara Pistocchi, ${ }^{2}$ Tiziana Sabbatini, ${ }^{2}$ Rudy Rossetto, ${ }^{2}$ Enrico Bonari \\ ${ }^{1}$ Dipartimento di Agronomia e Gestione dell'Agroecosistema, Università di Pisa; ${ }^{2}$ Land Lab, Scuola \\ Superiore S. Anna, Pisa, Italy
}

\begin{abstract}
The farm can be considered as the decision unit in the agricultural land management, therefore it is the most suitable scale to analyse the farmers' strategies of production. In this paper we describe the results of a comparison between two enquiries carried out in 1992-93 and 2009-10 on more than 30 farms, corresponding to about 1500 ha of utilised agricultural area (UAA), within the boundaries of the San Rossore, Migliarino, Massaciuccoli Regional Park (central-western Italy). We calculate a set of agri-environmental indicators both at territory and farm scale in order to point out the changes occurred over almost twenty years in the farms' structure, management and production features. The results showed that the major differences were related to fertilisers management (clearly decreasing), to the reduction of some crop types (industrial crops) and to the strong decrease of the gross marketable production. Furthermore, apparently stable indicators, such as the utilised agricultural area and the farm tractors' power, were actually the result of the compensation of contrasting trends. Farmers' behaviours were substantially homogeneous within the same typology of farm, highlighting common evolution strategies. The desirability of the occurred changes was also evaluated, underlining the improvement of environmental sustainability of the current cropping systems and a greater social acceptability of agricultural activities, while the evaluation from the farmers' point of view was less satisfactory.
\end{abstract}

Correspondence: Dr. Nicola Silvestri, Dipartimento di Agronomia e Gestione dell'Agroecosistema, Università di Pisa, via S. Michele degli Scalzi 2, 56124 Pisa, Italy. Tel. +39.050 .2218951 - Fax: +39.050 .2218970 .

E-mail: nsilve@agr.unipi.it

Key words: farming systems, agri-environmental indicators, agricultural trajectories, stakeholders analysis.

Received for publication: 3 October 2011.

Accepted for publication: 1 December 2011.

(C) Copyright N. Silvestri et al., 2012

Licensee PAGEPress, Italy

Italian Journal of Agronomy 2012; 7:e20

doi:10.4081/ija.2012.e20

This article is distributed under the terms of the Creative Commons Attribution Noncommercial License (by-nc 3.0) which permits any noncommercial use, distribution, and reproduction in any medium, provided the original author(s) and source are credited.

\section{Introduction}

The farm is a portion of territory under the control of an entrepreneur and can be considered as an elementary unit where homogeneous management criteria are applied. The farmer, after evaluating the specific environmental, technological and economic boundary conditions, makes his decisions about the cropping systems' structure and functions (Marten, 1988; Silvestri, 2001).

Consequently, the decision of choosing the farm as a subject of investigation in the study of production systems at territorial scale is related to the purpose of bringing out and analysing the farmer's strategies (Bockstaller et al., 1997; Bechini and Stöckle, 2007; Kempen et al., 2011; Righi et al., 2011). At smaller scales those characteristics could be biased by data aggregation thus reducing their variability, while at grater scale they could be influenced by specific cultural conditions which make the observed behaviours more difficult to be interpreted (Volk and Ewert, 2011).

Indicators are among the most effective tools to describe the farm management strategies as they allow a fast and effective assessment of the agricultural systems and of their consistency with the agronomic, economic and environmental goals (OECD, 2002; Giupponi and Carpani, 2006; Bechini and Castoldi, 2008).

This approach has undoubted benefits if compared to the experimental approach, which is unfit to extrapolate results at wider scales (Sharpley, 1995), and to simulation models, where complete data-sets are rarely available for applications at farm scale (Faivre et al., 2004). In agro-ecological assessments the most difficult aspect to investigate is the nature of the occurred changes, i.e. the dynamics of farmers' behaviour over time, the evaluation of their effectiveness and the prediction of future evolutions (Iraizoz et al., 2007; Silvestri and Bellocchi, 2007, 2008).

It is evident that the strategies adopted by farmers can have important effects on the environment, on the ecosystems and even on the organisation of human community (De Jager et al., 1998): this leads to extend the level of evaluation from a farm-private one (based on the farmer point of view) to a public-environmental one, (related to any potential negative externalities) and to a social-territorial one (concerning the social sharing of farmers' goals). These enhanced levels of evaluation are even more important when agricultural activities are carried out in particularly vulnerable areas (protected areas, nitrates vulnerable zones, Sites of Community Importance, etc.) and/or in areas subject to high social pressure (high number of inhabitants, territories with cultural, landscape and recreational values), where different and often contrasting goals have to be reconciled (McCown, 2002; Aubry, 2010).

In this paper we described and evaluated the changes (agricultural trajectories) observed in a twenty-year interval on a representative 
sample of farms located within the Regional Park of San Rossore, Migliarino, Massaciuccoli (central-western Italy), which shows many of the constraints mentioned above.

\section{Materials and methods}

\section{Study site}

The study site (about 7500 ha) is located in the Massaciuccoli lake catchment, which constitutes the northern part of the Regional Park, in the Provinces of Pisa and Lucca (Figure 1). Agriculture has spread in this territory since the Middle Ages and nowadays takes up a surface equals to $35 \%$ of the whole area (Cavalli and Cenni, 1997). The climate is classified as humid Mediterranean and it is considered as a climate of transition between the Mediterranean and the Continental ones. The mean annual rainfall is around $900 \mathrm{~mm}$, with two typical peaks in autumn and spring. The mean temperature is equal to $15^{\circ} \mathrm{C}$, while the mean minimum and maximum temperatures are respectively equal to $-2^{\circ} \mathrm{C}$ and $33^{\circ} \mathrm{C}$ (Cavalli and Cenni, 1997).

Once occupied by marshes, since 1930 most of the plan has been drained through a complex network of artificial ditches and pumping stations forcing water from the reclaimed land into the Massaciuccoli Lake. The areas surrounding the lake are characterised by peat soil, while in the southern part, clay loam, loam, and silt loam soils prevail, with a progressively decrease organic-matter content (Pistocchi $e t$ al., in press). Agriculture is traditionally oriented towards cereals and towards industrial and horticultural crops, with a significant presence of woody crops - especially olive and peach groves. Dairy productions are not widespread. The study site is located within a Nitrate Vulnerable Zone (NVZ) constituted by the whole lake catchment $\left(114 \mathrm{~km}^{2}\right.$, established in 2003 by the Regional act $n$. 172). The lake and the nearby palustrine areas represent one of the most important residual coastal marshy areas in Tuscany as well as a RAMSAR site, currently affected by heavy eutrophication phenomena.

Finally, near the agricultural areas there are two quite large settlements (Viareggio-Torre del Lago Puccini and Vecchiano-Nodica), for a total of 40,000 inhabitants. Industrial and commercial sites take up about 47 ha (Silvestri and Bonari, 2010). Furthermore, major touristy and cultural activities take place during summer. In the recent past the palustrine areas also held recreational functions (hunting and fishing in the lake).

\section{Data collection}

Two distinct enquiries among farmers were carried out in 1992-93 (Bonari and Silvestri, 1993) and 2009-10 (Baneschi et al., 2010). In order to detect the main farms' managerial and structural features, the farm manager, whether he was the owner or a charged technician, was interviewed by a member of the research team following a semi-structured form. The questionnaire was organized in two parts: the first one (farm-scale) aimed at collecting some general information: boundaries, ownership, tenancy, labour, crops surface, irrigated areas, tractors' power, livestock, etc.; the second one (crop-scale) dedicated to quantify the use of external inputs and the perfomance for each crop: fertilizers, yield, tillage systems, etc.

To make the collected data comparable, only the farms censed in both enquiries were included in the analysis and the possible trends in land property and real estate (division/fusion of farms) were also taken into account. We censed 31 farms, which corresponds to more than half the utilised agricultural area (2616 ha) and the total number of farms (58) in the study area. The consistency of the collected data was checked by various methods. Through the use of GIS tools, the declared utilised agricultural area (UAA) and cropland surfaces were compared with farm

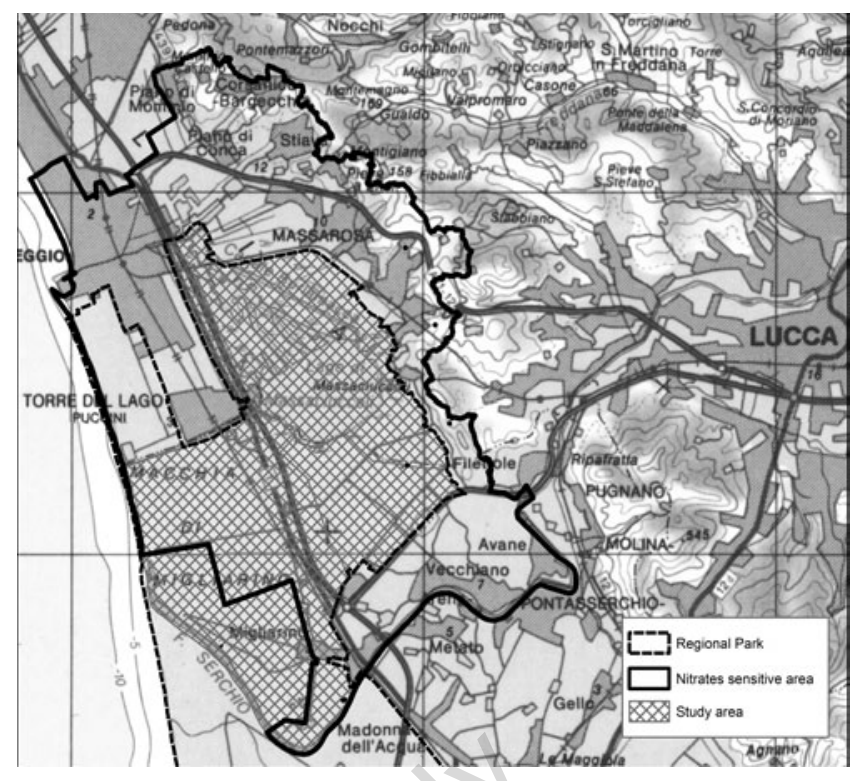

Figure 1. Studied area and boundaries of the Regional Park and the Nitrate Vulnerable Zone.

boundaries on a technical map; the composition of crop rotations were compared with the crops surfaces that farmers had actually declared in the surveyed years, in order to understand whether their declarations were consistent or not; the tractors were surveyed directly in the machinery shed and finally the use of fertilizers was checked on fertilization plans computed by farmers.

We chose the following indicators on the basis of the type of collected information, data accuracy/precision, diagnostic/informative value and significance in terms of private, public or social utility: UAA, surface of main crop types: summer cereals (SCe), winter cereals (WCe), industrial crops (ICr); fodder crops (FCr); horticultural crops ( $\mathrm{HCr}$ ); permanent crops (PCr); length of crop rotation (LCR); irrigated area (IrA); tractors' power (TrP); tillage energy requirement (TER); nitrogen amount (NiA); phosphorus amount (PhA); nitrogen balance (NiB); phosphorus balance $(\mathrm{PhB})$; labour requirement (LaR); crops yield index (CYI) and gross marketable production (GMP). Indicators' description and calculation details at territory and farm-scale are listed in Table 1.

\section{Data processing}

At territory-scale, we compared the overall values of the two enquiries calculated for each indicators as the sum of the farms' values. For the comparison among farms of different sizes, we used the indicator values computed in two different ways: the farm-scale indicators values (SCe, WCe, ICr, FCr, HCr, PCr, LCR, IrA, TrP, LaR) were obtained dividing the farm value by the relative UAA, while the crop-scale indicators values (TER, NiA, PhA, NiB, PhB, CYI, GMP) were computed as the sum of all crops' values divided by the UAA of the whole farm (weighted mean). UAA and LCR were two exceptions: the first one because it did not need to be divided by itself and the second one because it was a rotation-scale indicator and hence the mean was weighted on the rotations surface.

The observed changes at territory-scale were quantified in absolute and relative terms, by calculating the difference between the indicator values of the last (2009-2010) and the first (1992-1993) enquiry (Table 2). We also evaluated the positive or negative changes occurred to the indicators in terms of farms hectares (Figure 2). We considered as positive, a change where the 2009-10-indicator value was higher than the value 
Table 1. List and description of indicators at farm and territory-scale.

\begin{tabular}{|c|c|c|c|c|c|c|}
\hline Code & Indicator & Description & $\begin{array}{r}\text { Un } \\
\text { Farm-scale }\end{array}$ & Territory-scale & Equation & Territory-scale $^{\circ}$ \\
\hline UAA & Utilised agricultural area & Sum of cultivated areas & ha & ha & $\sum_{i} S_{i}$ & $\sum_{i=1} \sum_{i} S_{i}$ \\
\hline SCe & Summer cereals & $\begin{array}{l}\text { Sum of the areas cultivated } \\
\text { with summer cereals }\end{array}$ & $\%$ & ha & $\frac{\sum_{i} S_{i S C e}}{U A A} 100$ & $\sum_{i=1}^{n} \sum_{i} S_{i S C e}$ \\
\hline WCe & Winter cereals & $\begin{array}{l}\text { Sum of areas cultivated with } \\
\text { winter cereals }^{\#}\end{array}$ & $\%$ & ha & $\frac{\sum_{i} S_{i W C e}}{U A A} 100$ & $\sum_{i=1}^{n} \sum_{i} S_{i W C e}$ \\
\hline $\mathrm{ICr}$ & Industrial crops & $\begin{array}{l}\text { Sum of the areas cultivated } \\
\text { with industrial crops }{ }^{\#}\end{array}$ & $\%$ & ha & $\frac{\sum_{i} S_{i I C r}}{U A A} 100$ & $\sum_{i=1}^{n} \sum_{i} S_{i \overline{l C} r}$ \\
\hline $\mathrm{FCr}$ & Fodder crops & $\begin{array}{l}\text { Sum of the areas cultivated } \\
\text { with fodder crops }{ }^{\#}\end{array}$ & $\%$ & ha & $\frac{\sum_{i} S_{i F C r}}{U A A} 100$ & $\sum_{i=1}^{n} \sum_{i} S_{i F C r}$ \\
\hline $\mathrm{HCr}$ & Horticultural crops & $\begin{array}{l}\text { Sum of the areas cultivated } \\
\text { with horticultural crops }\end{array}$ & $\%$ & ha & $\frac{\sum_{i} S_{i H C r}}{U A A} 100$ & $\sum_{i=1}^{n} \sum_{i} S_{i H C r}$ \\
\hline $\mathrm{PCr}$ & Permanent crops & $\begin{array}{l}\text { Sum of the areas cultivated } \\
\text { with permanent crops }\end{array}$ & $\%$ & ha & $\frac{\sum_{i} S_{i P C r}}{U A A} 1$ & $\sum_{i=1}^{n} \sum_{i} S_{i P C r}$ \\
\hline LCR & Length of crops rotation & $\begin{array}{l}\text { Total number of years of } \\
\text { crop rotations }^{\S}\end{array}$ & Y & & $\frac{\sum_{j} S_{j} L_{j}}{U A A}$ & $\frac{\sum_{j} S_{j} L_{j}}{U A A_{i}}$ \\
\hline IrA & Irrigated zrea & $\begin{array}{l}\text { Total agricultural area that } \\
\text { is irrigated }\end{array}$ & $\%$ & ha & $\frac{S_{I r A}}{U A A} 100$ & $\sum_{i=1}^{n} S_{I r A l}$ \\
\hline $\operatorname{TrP}$ & Tractors power & $\begin{array}{l}\text { Total power of agricultural } \\
\text { tractors }\end{array}$ & ha & $\mathrm{kW}$ & $\frac{\sum_{k} P_{k}}{U A A}$ & $\sum_{i=1}^{n} \sum_{k} P_{k}$ \\
\hline TER & $\begin{array}{l}\text { Tillage energy } \\
\text { requirement }\end{array}$ & $\begin{array}{l}\text { Total energy requirement } \\
\text { for soil tillage operations }\end{array}$ & MJ hat ${ }^{-1} y^{-1}$ & 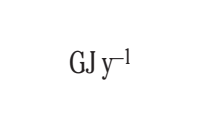 & $\frac{\sum_{i} S_{i} E R_{i}}{U A A}$ & $\sum_{i=1}^{n} \sum_{i} S_{i} E R_{i}$ \\
\hline $\mathrm{NiA}$ & Nitrogen amount & $\begin{array}{l}\text { Total } N \text { amount from external } \\
\text { fertilisers (purchased) }\end{array}$ & $\mathrm{kg} \mathrm{ha}^{-1} \mathrm{y}^{-1}$ & $t y^{-1}$ & $\frac{\sum_{i} S_{i} A_{N_{i}}}{U A A}$ & $\sum_{i} S_{i} A_{N_{i}} \frac{1}{10^{3}}$ \\
\hline PhA & Phosphorus amount & $\begin{array}{l}\text { Total P amount from external } \\
\text { fertilisers (purchased) }\end{array}$ & $\mathrm{kg} \mathrm{ha}^{-1} \mathrm{y}^{-1}$ & $t y^{-1}$ & $\frac{\sum_{i} S_{i} A_{P_{i}}}{U A A}$ & $\sum_{i} S_{i} A_{P_{i}} \frac{1}{10^{3}}$ \\
\hline $\mathrm{NiB}$ & Nitrogen balance & $\begin{array}{l}\text { Total N input - total N output } \\
\text { (plant uptake) }\end{array}$ & $\mathrm{kg} \mathrm{ha}^{-1} \mathrm{y}^{-1}$ & $t y^{-1}$ & $\frac{\sum_{i}\left(A_{N_{i}}-Y_{i} C_{N i}\right) S_{i}+S l_{N}}{U A A}$ & $\sum_{=1}^{n} N_{i B_{l}} U A A_{l} \frac{1}{10^{3}}$ \\
\hline $\mathrm{PhB}$ & Phosphorus balance & $\begin{array}{l}\text { Total } \mathrm{P}_{2} \mathrm{O}_{5} \text { input - total } \mathrm{P}_{2} \mathrm{O}_{5} \\
\text { output (plant uptake) }\end{array}$ & $\mathrm{kg} \mathrm{ha}^{-1} \mathrm{y}^{-1}$ & $t y^{-1}$ & $\frac{\sum_{i}\left(A_{P_{i}}-Y_{i} C_{P_{i}}\right) S_{i}+S l_{P}}{U A A}$ & $\sum_{i=1}^{n} P h B_{l} U A A_{l} \frac{1}{10^{3}}$ \\
\hline $\mathrm{LaR}$ & Labour requirement & $\begin{array}{l}\text { Total number of annual work } \\
\text { units (AWU) }\end{array}$ & AWU ha-1 $y^{-1}$ & AWU $^{-1}$ & $\frac{A W U}{U A A}$ & $\sum_{l=1}^{n} A W U_{l}$ \\
\hline CYI & Crops yield index & $\begin{array}{l}\text { Mean of the ratios between } \\
\text { actual yield and the } \\
\text { target yield }\end{array}$ & $\%$ & $\%$ & $\frac{\sum_{i} S_{i} Y_{i} / Y r_{i}}{U A A} 100$ & $\frac{\sum_{i} S_{i} Y_{i} / Y r_{i}}{\sum^{n} U A A_{i}} 100$ \\
\hline GMP & $\begin{array}{l}\text { Gross marketable } \\
\text { production }\end{array}$ & $\begin{array}{l}\text { Revenue from the sale } \\
\text { of crops production }\end{array}$ & $€ \mathrm{ha}^{-1} \mathrm{y}^{-1}$ & Million $€ \mathrm{y}^{-1}$ & $\frac{\sum_{i} Y_{i} P_{i}}{U A A}$ & $M P_{l} U A A_{l} \frac{1}{10^{6}}$ \\
\hline
\end{tabular}

$\mathrm{S}_{\mathrm{i}}$, surface of a crop or crop category $i(\mathrm{ha}) ; U A A$, utilised agricultural area of the considered farm; $L_{j}$, length of a crop rotation $j(\mathrm{y}) ; S_{l k}$, irrigated area of the considered farm; $P_{k}$, power of a tractor $k(\mathrm{~kW}) ; E R_{i}$, energy requirement for the primary tillage operations ( $\mathrm{MJ} \mathrm{ha}^{-1} \mathrm{y}^{-1}$ ) on the $i_{t h}$ crop; $A_{i}, \mathrm{~N}$ or $\mathrm{P}_{2} \mathrm{O}_{5}$ amount from purchased fertilisers supplied to $i^{\text {th }}$ crop $\left(\mathrm{kg} \mathrm{ha}^{-1} \mathrm{y}^{-1}\right) ; S l, \mathrm{~N}_{\text {or }} \mathrm{P}_{2} \mathrm{O}_{5}$ amount from animal slurry (kg $\mathrm{y}^{-1}$ ); $Y_{i}$, crop actual vield for the $i^{\text {th }}$ crop (kg ha ${ }^{-1} \mathrm{y}^{-1}$ ); $C_{i}$, crop $\mathrm{N}$ or $\mathrm{P}_{2} \mathrm{O}_{5}$ content in the harvestable product for the $i^{\text {th }}$ crop i.e. without considering nutrients in residues left on the field (\%); $A W U$, annual works units (hours $\left.y^{-1}\right) ; A W U_{l}, 2200$ hours of labour; $Y r_{i}$, crop target yield fixed for the $i^{\text {th }}$ crop ( $\mathrm{kg}$ $\left.\mathrm{ha}^{-1} \mathrm{y}^{-1}\right) ; P_{i}$, market price (in 2010) for the $l^{t h} \mathrm{crop}\left(€ \mathrm{~kg}^{-1}\right)$. ${ }^{\circ}$ The index I is referred to the $t^{t h}$ farm, with I going from $/ \mathrm{to} \mathrm{n}=31$; \# in the case of two crops per year the corresponding surface was counted twice (e.g. short-cycle horticultural crops); $\$$ some crops out of the rotation (e.g. artichoke, asparagus, fruit or olive trees) the LRC was fixed considering a conventional life-cycle of the plantation (10y for olive and poplar groves, $7 \mathrm{y}$ for orchards, $4 \mathrm{y}$ for artichoke and asparagus). 
formed by using R statistical software (version 2.12.0, R Foundation for

of the first enquiry plus $10 \%$; changes within a range of $\pm 10 \%$ were considered as negligible and when the 2009-10-indicator value was lower than the corresponding value in 1992-93 minus $10 \%$, the change was considered as negative. We then summed up the areas falling in each of the three categories separately for each indicator.

To evaluate the desirability of the occurred changes we classified the indicators in three categories: private, public and social indicators, according to their capability to represent the interests of different stakeholders. This assignment was made on the basis of focus groups organised with different local stakeholders. Three main meetings were organized in the presence of about 60 people equally divided by the involved interest groups: farmers, decision makers, environmentalist, researchers, tourist operator, teachers, citizens, etc. According to the orientation (concordant if desirability increased together with the indicator value, discordant in the opposite case) and to the magnitude of the changes (in percentage, Table 2) we identified five classes of desirability: +2 (for positive changes greater than $+50 \%$ ), +1 (for positive changes within the $+50 \div+10 \%$ range), 0 (for changes within the range $\pm 10 \%$ ), -1 (for negative changes within the $-50 \div-10 \%$ range) and -2 (for negative changes less than $+50 \%$ ). The overall rating (OR) of desirability was obtained by averaging the classed values, in order to eliminate the effect of a different number of indicators in each category. Finally, to highlight the different adaptive strategies applied by farmers, we performed a hierarchical cluster analysis, where farms were considered as elements and indicators at farm-scale as variables. After standardisation (dividing each value by the variable mean), the clustering was performed on both enquiries' data separately and followed by the analysis of the membership changes that occurred within each cluster. We chosen the complete linkage clustering, where clusters are merged on the basis of the maximum distance between the elements of each cluster (Sokal and Michener, 1958). Statistical analyses were per-

Table 2. Indicators values at territory-scale for the two surveyed years and their absolute and percent differences.

\begin{tabular}{|c|c|c|c|c|c|}
\hline Code & Units & 1992-93 & 2009-2010 & $\begin{array}{c}\text { Diff } \\
\text { Absolute }\end{array}$ & $\begin{array}{l}\text { nces } \\
\text { Percent }\end{array}$ \\
\hline UAA & ha $y^{-1}$ & 1634 & 1509 & -125 & -8 \\
\hline SCe & ha $y^{-1}$ & 619 & 700 & 81 & 12 \\
\hline WCe & ha $y^{-1}$ & 216 & 331 & 115 & 35 \\
\hline $\mathrm{ICr}$ & ha $y^{-1}$ & 599 & 232 & -367 & -158 \\
\hline $\mathrm{FCr}$ & ha $y^{-1}$ & 34 & 43 & 9 & 21 \\
\hline $\mathrm{HCr}$ & ha $y^{-1}$ & 335 & 149 & -186 & -125 \\
\hline $\mathrm{PCr}$ & ha $y^{-1}$ & 36 & 115 & 79 & 69 \\
\hline LCR & $\mathrm{y}$ & 2779 & 3446 & 667 & 19 \\
\hline IrA & ha $y^{-1}$ & 768 & 485 & -283 & -58 \\
\hline $\operatorname{TrP}$ & $\mathrm{kW}$ & 5741 & 6035 & 294 & 5 \\
\hline TER & $\mathrm{GJ}^{-1}$ & 4214 & 3075 & -1139 & -37 \\
\hline $\mathrm{NiA}$ & $t y^{-1}$ & 386 & 201 & -185 & -92 \\
\hline $\mathrm{PhA}$ & $t y^{-1}$ & 231 & 79 & -152 & -191 \\
\hline $\mathrm{NiB}$ & $t y^{-1}$ & 270 & 83 & -187 & -224 \\
\hline $\mathrm{PhB}$ & $\mathrm{ty}^{-1}$ & 225 & 45 & -180 & -399 \\
\hline LaR & $\mathrm{AWUy}^{-1}$ & 68 & 55 & -13 & -24 \\
\hline CYI & $\%$ & 91 & 88 & -3 & -4 \\
\hline GMP & million $€$ & 4.91 & 3.11 & -1.80 & -58 \\
\hline
\end{tabular}

UAA, surface of main crop types; SCe, summer cereals; WCe, winter cereals; $\mathrm{ICr}$, industrial crops; FCr, fodder crops; $\mathrm{HCr}$, horticultural crops; $\mathrm{PCr}$, permanent crops; LCR, length of crop rotation; IrA, irrigated area; TrP, tractors power; TER, tillage energy requirement; NiA, nitrogen amount; PhA, phosphorus amount; $\mathrm{NiB}$, nitrogen balance; $\mathrm{PhB}$, phosphorus balance; LaR, labour requirement; CYI, crops yield index; GMP, gross marketable production.
Statistical Computing, http://www.r-project.org).

\section{Results and discussion}

The indicators' values at territory-scale for both periods as well as the corresponding absolute and percent differences are listed in Table 2. The greatest absolute differences were observed in the surface of different crop types, as a great decrease in industrial and horticultural crops (-367 and -186 ha respectively) corresponded to an increase on both winter and summer cereals $(+115$ and +81 ha respectively). These changes led to a moderate increase in LCR mainly due to the larger presence of WCe (as interruption of maize continuous cropping), $\mathrm{PCr}$ and FCr.

We also found major differences in the amount of both nitrogen and phosphorus from external fertilisers, which decreased markedly (-185 t for nitrogen and -152 $\mathrm{t}$ for phosphorus).

The decrease observed for the nitrogen balance $(-187 \mathrm{t})$ was substantially equivalent to that of $\mathrm{NiA}$, due to the effect of the decrease of animal slurry production balanced by an equivalent decrease of crops uptake. Instead, in the case of phosphorus, the amount of plant uptake

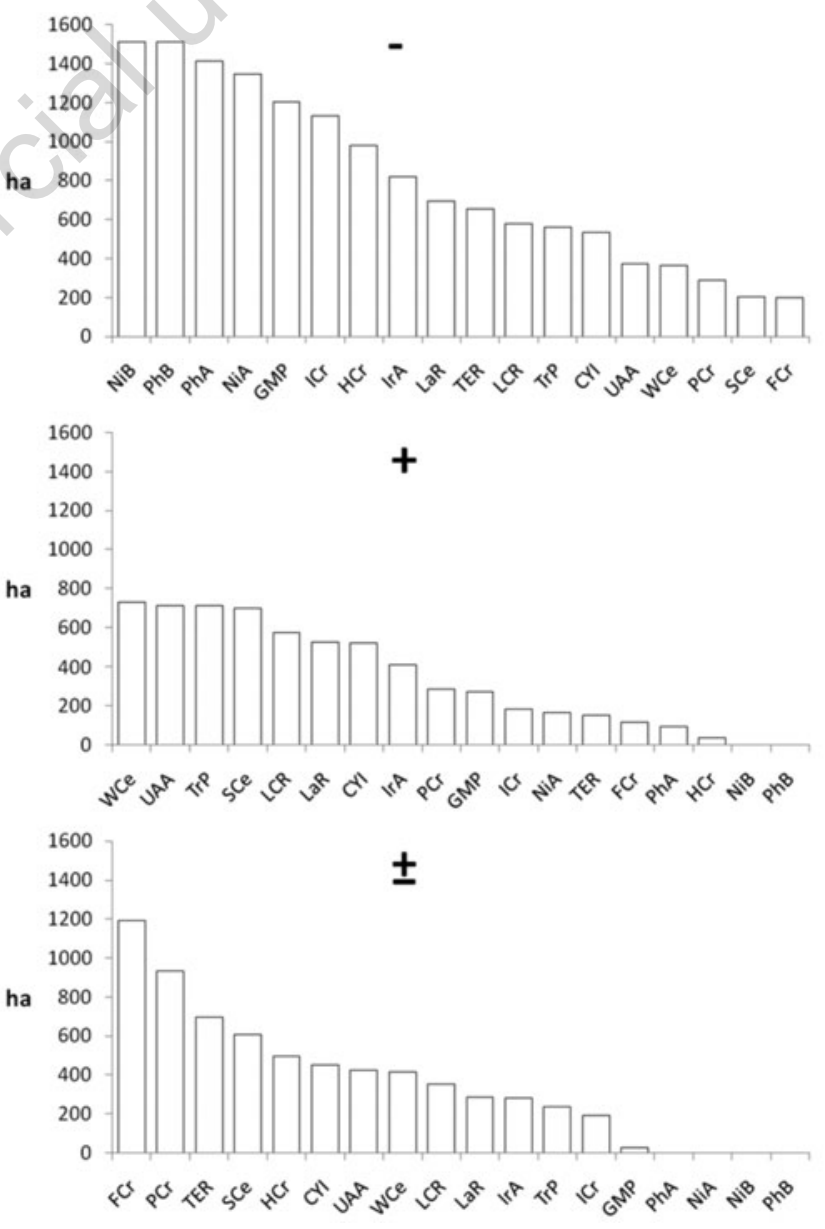

Figure 2. Changes occurred to the indicators $(-=$ negative changes, $+=$ positive changes, $\pm=$ negligible changes $)$ in terms of hectares of farms utilised agricultural area in 2009-2010. 
remained constant over time and the decrease of animal slurry production determined the observed change of PhB (-180 t). GMP per ha changed significantly, as the crop yield index remained unchanged (CYI $=-0.03$ ), this is almost exclusively related to the fact that farmers have chosen to grow different crops.

Relative changes were negligible for what concerns CYI, TrP and UAA $(-3,+5$ e $-8 \%$ respectively); positive changes (within the range of 10 to $50 \%$ ) were detected in SCe, LCR, FCr and WCe, wihle LaR and TER changed negatively within the same range. Changes greater than $50 \%$ were detected in IrA (-58\%), GMP (-58\%) and PCr (+69\%), and even more significant differences (more than 100\%) were observed for the remaining indicators related to crop extent ( $\mathrm{HCr}$ and $\mathrm{ICr}$ ) and to fertilization management (NiA, PhA, NiB and PhB).

On the whole, over the considered twenty-year period, farmers have pursued a significant extensification of their production systems, by reducing the use of external inputs, as the decreasing trend of all the related indicators (LaR, TER, NiA, $\mathrm{PhA}, \mathrm{NiB}$ and $\mathrm{PhB}$ ) shows. At the same time, high-inputs and labour-intensive cropping systems (i.e. horticultural and industrial crops) have reduced their incidence in favor of less demanding crops (winter cereals and woody crops). Moreover, the negative trend of industrial crops was influenced also by the end of the sugar beet cultivation due to the neighboring sugar mills closure in the half of 1990s. The increase of SCe (almost exclusively maize) is partially in contrast with this trend. The strong suitability of this land for this crop (shallow water table which allows also the rainfed cultivation, slightly acidic soils and high soil organic matter content), confirmed maize as the key-crop.

The crops yield index stability, despite the changes (reduction of NiA and $\mathrm{PhA}$ ), can be explained both by the increase of less demanding crop cultivation and by the improvement of fertilization practices, which previously exceeded the actual crops requirements, as also found in other Italian protected areas (Bechini and Castoldi, 2006; Castoldi et al., 2009).

Conversely, GMP was penalized and, although these results do not automatically entail a decrease of farmers' income - since also the costs of production have been reduced - this is an indicator of the difficult economic situation the agricultural sector is facing. Farmers' behaviour proved to be correct under an agronomic point of view, as they achieved the reduction of operating costs through consistent changes in practices and crops choice.

In Figure 2 the changes occurred to the indicators in terms of hectares of farms' UAA are plotted. The more extensive changes affected the use of fertilisers: $\mathrm{NiA}, \mathrm{PhA}, \mathrm{NiB}$ and $\mathrm{PhB}$ decreased over almost the whole censed UAA. The GMP decrease affected farms with a total UAA of 1200 ha, while ICr and $\mathrm{HCr}$ showed negative changes over 1100 and 1000 ha respectively; significant reductions were also observed for IrA (around $800 \mathrm{ha}$ ) and LaR (around $700 \mathrm{ha}$ ).
For what concerns WCe, UAA, TrP and SCe positive changes affected more hectares of UAA (700 hectares in average) than negative ones did. The indicator showing negligible changes over the largest surface was TER (around 700 ha), since the surfaces computed for $\mathrm{FCr}$ and $\mathrm{PCr}$ (1200 and 900 ha respectively with negligible changes) cannot be considered as indicative. Indeed these surfaces also include the UAA of farms without fodder (1176 ha) nor permanent crops (918 ha), which did not change from this point of view.

Hence, among different options, farmers greatly seemed to prefer to modify the management of fertilisers; a certain flexibility was also displayed in the choice of crops, as industrial and horticultural crops showed a clear tendency to change and summer and winter cereals showed an intermediate trend, while fodder and permanent crops cannot be properly evaluated because of their little diffusion in this territory. IrA and LaR, conventionally considered as rigid choices, as they are partly related to the allocation of fixed factors, showed a rather scarce stability: the hectares of UAA affected by negligible changes were less than $300 \mathrm{ha}$. The reasons of this trend were related for the former to the decrease of irrigation water quality and for the latter to the decline of more labour-demanding crops. As a result of the variability described above, we observed a marked change in the GMP, which is the indicator that varied over the most part of the UAA, after the fertilisers management indicators.

Finally, it is important to underline that at least four indicators changed positively (+), negatively (-) or negligibly ( \pm ) over almost equals portions of surfaces (not unidirectional changes): CYI (-533, $\pm 453,+523$ ha $),$ LCR $(-582, \pm 353,+575$ ha $), \operatorname{TrP}(-563, \pm 237,+710$ ha $)$ and UAA $(-376, \pm 423,+711 \mathrm{ha})$. Besides, these underwent less in percent changes (Table 2). Hence their stability is only apparent, being the results of reciprocal compensations. With respect to these choices farmers did not show homogeneous behaviours, which may be caused either by personal beliefs or current conditions rather than to the influence of more general factors.

The results of cluster analyses performed for both periods are showed in Table 3. According to the same value of Euclidean distance we obtained six clusters for both periods. The mean values of indicators at farm-scale of each cluster are plotted in Figure 3. According to the censed crop types the clusters can be classified in two groups: the first one, containing clusters I, II and III, characterised by farms specialised in one crop type (fodder, permanent or horticultural crops); the second one with farms where the UAAs assigned to different crop types (winter and summer cereals, industrial crops) are comparable: clusters IV, V and VI. A substantial consistency in the clusters composition resulting from the two analyses can be observed, even though they are not completely overlapping: 22 farms out of 31 indeed did not change their membership in the two analyses. This means that the farms belonging to each cluster have chosen similar adaptive strategies (Figure 3). Farms of cluster

Table 3. Changes of membership in 1992-93 and 2009-10 clusters.

\begin{tabular}{lccl} 
Cluster & N. of members in 1992-93 & N. of members in 2009-10 & \multicolumn{1}{c}{ Differences } \\
I & 3 & 5 & +2 farms from cluster V \\
II & 3 & 4 & +1 farm from cluster V \\
\hline III & 3 & 5 & +2 farms from cluster V \\
IV & 9 & 9 & +3 farms: 2 from cluster V and VI and 1 new farm \\
\hline & 11 & 7 & -3 farms to cluster V and 1 farm acquired by an existing one \\
V & 2 & 1 & +2 farms from cluster IV \\
VI & 31 & 31 & -6 farms: 1 to cluster IV, 2 to cluster III, 2 to cluster I, 1 to cluster II \\
Total & & & +1 farm to cluster IV \\
& & & -1 (farm acquired by an existing one)
\end{tabular}


$\mathrm{V}$, characterised by mixed cropping systems, reduced their irrigated surface and horticultural crops to favour winter cereals and strongly decreased the use of fertilisers. Farms of cluster IV also dramatically reduced the use of chemical inputs and only partially modified their crop choice, with maize remaining the most widespread crop. Farms of cluster III, originally oriented towards horticultural crops, reduced them significantly thus favouring winter and summer cereals and also reduced their level of mechanisation (TrP) and labour requirement (LaR). Farms of cluster I strongly reduced the fodder crops cultivation thus favouring
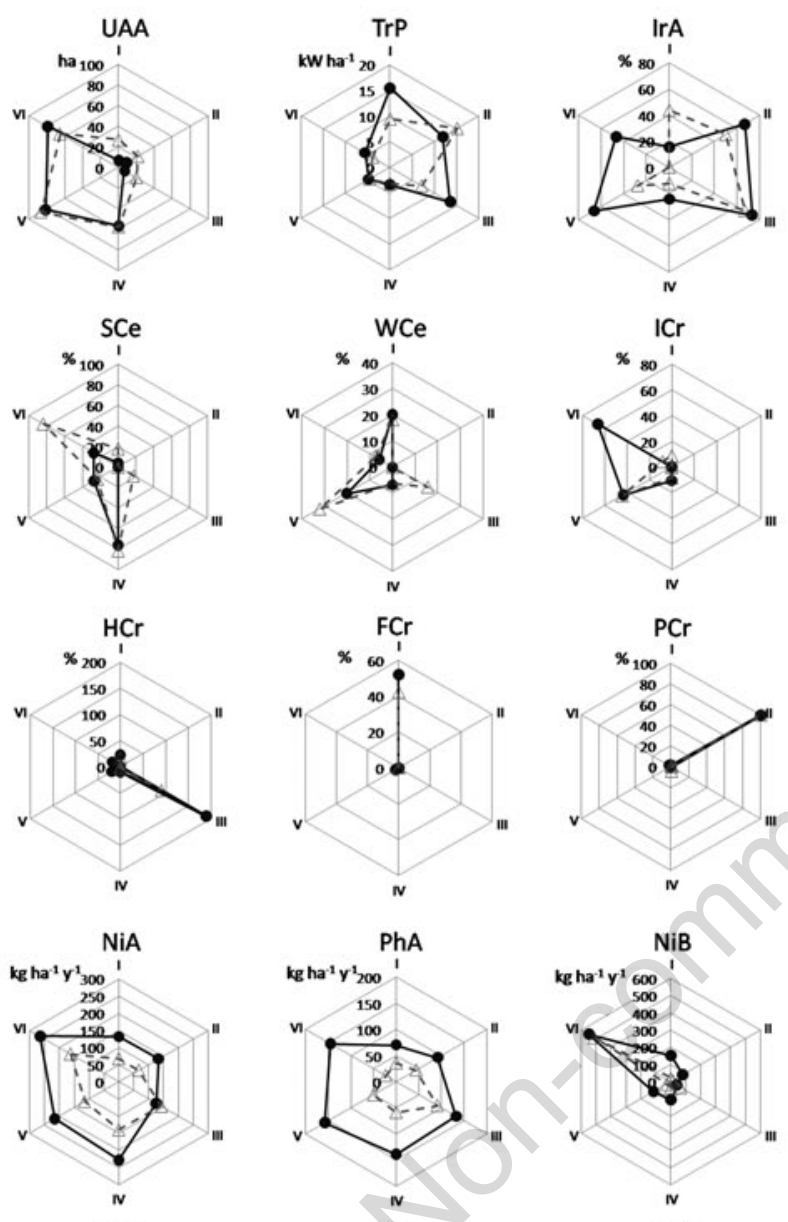

$\mathrm{PhB}$
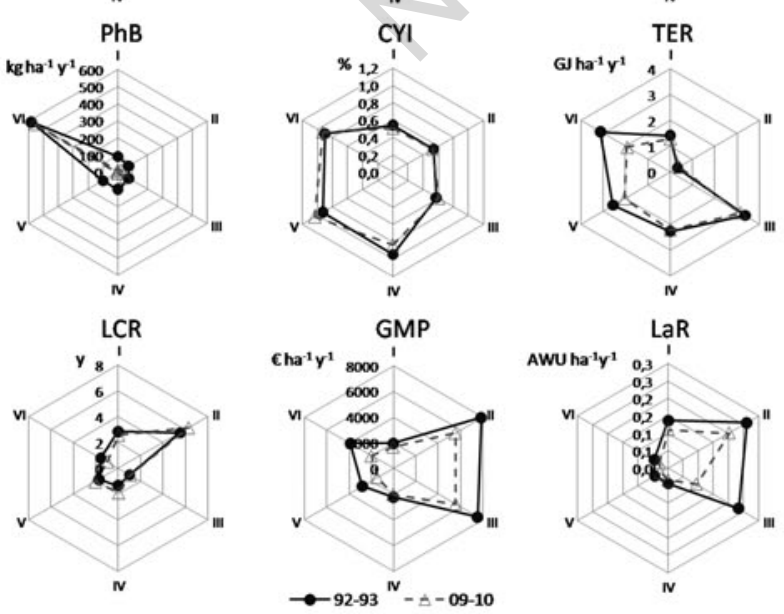

summer cereals and industrial crops and decreased their TrP and nutrients balances, but increased their irrigated area. Farms of cluster II, oriented towards woody crops, did not change their cropping systems, but reduced fertilisers' application rates and labour. Finally farms of cluster VI, characterised by mixed cropping systems moved towards the reduction of industrial and horticultural crops and the corresponding increase of summer cereals, while decreasing fertilisers' application rates and irrigation. Most of farms (6 farms out of 9) that changed their cluster membership, moved from cluster $\mathrm{V}$, where cropping systems based on industrial crops prevailed, to cropping systems with different key-crops: fodder crops (cluster I), horticultural crops (cluster III), woody crops (cluster II) or summer cereals (cluster IV).

In Table 4 the evaluations about change desirability are reported. Although the methodology is rather simplified, it clearly showed that the new farms strategies may be positively evaluated $(\mathrm{OR}=+1.7)$ in publicenvironmental terms, tanks to the increase of fodder and permanent crops and to the reduction of tillage and fertilisers amount. The evaluation in social terms was more uncertain, although slightly positive $(\mathrm{OR}=$ $+0.4)$, thanks to the general reduction of irrigated areas and the increase in the length of crop rotations, which partly balanced the decrease in the extent of vegetable crops cultivation and of labour employment. From the farmers' point of view (private-farm level) the desirability of change seemed to be rather less satisfactory $(\mathrm{OR}=-0.5)$, mainly due to the effect of GMP and the decrease in industrial crops.

Therefore, an effort should be made in order to identify productive strategies suitable to align farmers' goals (maximisation of income) with social expectations and needs (employment increase, less competition on limited resources such as water, soil fertility maintenance, etc.). Economic issues have forced farmers to reduce the use of external inputs and improve the environmental sustainability of cropping

Table 4. Rating of desirability of changes of farmers' behaviour at private-farm, public-environmental and social-territorial level.

\begin{tabular}{lccc} 
Code & Indicator category & Orientation $^{\circ}$ & Rating $^{\#}$ \\
UAA & Private & Concordant & 0 \\
SCe & Private & Concordant & +1 \\
ICr & Private & Concordant & -2 \\
TrP & Private & Concordant & 0 \\
CYI & Private & Concordant & 0 \\
GMP & Private & Concordant & -2 \\
OR (mean) & & & -0.5 \\
FCr & Public & Concordant & +1 \\
PCr & Public & Concordant & +2 \\
TER & Public & Discordant & +1 \\
NiA & Public & Discordant & +2 \\
PhA & Public & Discordant & +2 \\
NiB & Public & Discordant & +2 \\
PhB & Public & Discordant & +2 \\
OR (mean) & & & +1.7 \\
IrA & Social & Discordant & +2 \\
HCr & Social & Concordant & -2 \\
WCe & Social & Concordant & +1 \\
LCR & Social & Concordant & +2 \\
LaR & Social & Concordant & -1 \\
OR (mean) & & & +0.4 \\
\hline
\end{tabular}

${ }^{\circ}$ Concordant, desirability increases together with the indicator value; discordant, desirability decreases as the indicator value increases. ${ }^{\sharp}+2$, very desirable (changes greater than $+50 \%$ ); +1 , desirable (changes within the $+50 \div+10 \%$ range); 0 , indifferent (changes within $\pm 10 \%$ ); -1 , undesirable (change within the $-10 \div-50 \%$ range); -2 , very undesirable (changes less than $-50 \%$ ). UAA, surface of main crop types; $\mathrm{SCe}$, summer cereals; WCe, winter cereals; $\mathrm{ICr}$, industrial crops; $\mathrm{FCr}$, fodder crops; $\mathrm{HCr}$, horticultural crops; PCr, permanent crops; LCR, length of crop rotation; IrA, irrigated area; TrP, tractors power TER, tillage energy requirement; NiA, nitrogen amount; PhA, phosphorus amount; NiB, nitrogen balance; $\mathrm{PhB}$, phosphorus balance; LaR, labour requirement; CYI, crops yield index; GMP, gross marketable production; OR, overall rating.

Figure 3. Spider graphs representing mean indicators values at farm-scale for 1992-93 and 2009-10 clusters. 
systems. This change however was not trouble free in terms of income and seems to have started a process of landed properties restructuring (bipolarisation), which penalize medium size farms and favours on one hand the larger farms and on the other hand the smallholders (Buttel, 2001). In the first case the tendency to the extensification and the input costs lowering prevailed, while in the second case the reduction of costs is pursued by the use of household labour.

The overall UAA decreased (-8\%), but larger farms increased in size: as a matter of fact, the UAA that underwent positive changes (711 hectares) was larger than the UAA that was subject to negative changes (376 ha) (Figure 3). This is partially true also for TrP. The not unidirectional changes of CYI and LCR seemed to confirm these two contrasting trends.

\section{Conclusions}

The changes in the farmers' behaviour observed over almost twenty years were numerous and remarkable. Farmers modified reduced significantly the use of productive factors (fertilisers, tillage, irrigation), but they also consistently modified the cropping systems structure, often by introducing less demanding species. This changes did not seem to affect crops yield, even though a decrease in GMP was observed, as the incidence of relatively less profitable crops increased.

The little variability displayed by the farms' size (UAA) and mechanization (TrP) is actually the result of reciprocal compensation effects; therefore it is not sure whether farmers will continue on their activity in the near future or not, especially in the case of medium size farms.

In the areas affected by changes, the tillage energy requirement (TER) and the land suitability for maize (SCe) were more stable than indicators traditionally considered as structural ones (UAA, TrP, LaR, IrA). With regard to the adaptive strategies, changes were substantially homogeneous within each cluster, with the exception of some industrial crops-oriented farms, which moved to different cropping system. Finally, the changes in the indicators' values over the study period highlighted that desirability for farmers was weak, while the environmental sustainability of the adopted cropping systems improved, which was partially true also for social desirability. In this regard, social learning activities could be a useful tool for improving social sharing of farmers' choices.

\section{References}

Aubry C, 2010. Sustainability of peri-urban agriculture. In: M.A Galli, S. Lardon, E. Marraccini and E. Bonari (eds.) Agricultural management in peri-urban areas. The experience of an international workshop. Felici Ed., Pisa, Italy.

Baneschi I, Basile P, Bonari E, Guidi M, Pistocchi C, Rossetto R, Sabbatini T, Silvestri N, 2010. The irrigation water consumption in the lake of Massaciuccoli catchment: agricultural needs and environmental management. Proc. 11th ESA Congr., Montpellier, France, pp 755-756.

Bechini L, Castoldi N, 2006. Calculating the soil surface nitrogen balance at region scale: example application and critical evaluation of tools and data. Ital. J. Agron. 4:665-676.

Bechini L, Castoldi N, 2008. Methodological aspects of on-farm monitoring of cropping systems management. Ital. J. Agron. 4:287-298.

Bechini L, Stöckle CO, 2007. Integration of a cropping systems simulation model and a relational database for simple farm-scale analysis.
Agron. J. 99:1226-1237.

Bockstaller C, Girardin P, van der Werf HMG, 1997. Use of agro-ecological indicators for the evaluation of farming systems. Eur. J. Agron. 7:261-270.

Bonari E, Silvestri N, 1993. Produzioni vegetali nel territorio del Parco. In: Lo studio dell'agricoltura all'interno del Parco. Pacini Ed., Pisa, Italy.

Buttel FH, 2001. Some reflections on late twentieth century agrarian political economy. Sociol. Ruralis. 41: 165-181.

Castoldi N, Bechini L, Stein A, 2009. Evaluation of the spatial uncertainty of agro-ecological assessments at the regional scale: the phosphorus indicator in northern Italy. Ecol. Indic. 9:902-912.

Cavalli S, Cenni M, 1997. Carta della natura e degli ambienti territoriali. S.EL.CA. Ed., Firenze, Italy.

De Jager A, Nandwa SM, Okoth PF, 1998. Monitoring nutrient flows and economic performance in Africa farming systems (NUTMON). I. Concepts and methodologies. Agr. Ecosyst. Environ. 71:37-48.

Faivre R, Leenhardt D, Voltz M, Benoit M, Papy F, Dedieu G, Wallach D, 2004. Spatialising crop models. Agronomie 24:205-217.

Giupponi C, Carpani M, 2006. Recent developments in indicators and models for agri-environmental assessment. Ital. J. Agron. 4:647-664.

Iraizoz B, Gorton M, Dadidova S, 2007. Segmenting farms for analysing agricultural trajectories: a case study of the Navarra region in Spain. Agr. Syst. 93:143-169.

Kempen M, Elberesen BS, Staritsky I, Andersen E, Heckelei T, 2011. Spatial allocation of farming systems and farming indicators in Europe. Agr. Ecosyst. Environ. 142:51-62.

Marten GG, 1988. Productivity, stability, sustainability equitability and autonomy as properties for agroecosystem assessment. Agr. Syst. 26: 291-316.

McCown RL, 2002. Changing systems for supporting farmers' decisions: problems, paradigms and prospects. Agric. Syst. 74: 179-220.

OECD, 2002. Agri-environmental indicators: recent progress and future directions. OECD Publ., Paris, France.

Pistocchi C, Silvestri N, Rossetto R, Sabbatini T, Guidi M, Baneschi I, Bonari E, Trevisan D, 2012. A simple model to assess $\mathrm{N}$ and $\mathrm{P}$ contamination in ungauged surface drainage networks. Application to the lake of Massaciuccoli catchment, Italy. J. Environ. Qual. (In press)

Righi E, Dogliottti S, Stefanini FM, Pacini GC, 2011. Capturing farm diversity at regional level to up-scale farm level impact assessment of sustainable development options. Agr. Ecosyst. Environ. 142:6374 .

Sharpley AN, 1995. Dependence of run-off phosphorous on extractable soil phosphorous. J. Environ. Qual. 24:920-926.

Silvestri N, Bellocchi G, 2007. Designing sustainable cropping systems: a general framework. Proc. Int. Symp. on Methodologies on Integrated Analysis on Farm production Systems, Catania, Italy 2:119-120.

Silvestri N, Bellocchi G, 2008. Rule-based handling of hazardous nitrogen. Ital. J. Agron. 3(Suppl.3):257-258.

Silvestri N, Bonari E, 2010. Peri-urban agriculture and water quality. Phosphorus pollution in Lake Massaciuccoli. In: M.A. Galli, S. Lardon, E. Marraccini and E. Bonari (eds.) Agricultural management in peri-urban areas. The experience of an international workshop. Pisa, Felici Ed., Italy.

Sokal RR, Michener CD, 1958. A statistical method for evaluating systematic relationship. University of Kansas Scientific Bullettin 38:1409-1438.

Volk M, Ewert F, 2011. Scaling methods in integrated assessment of agricultural systems - State-of-the-art and future directions. Agr. Ecosyst. Environ. 142:1-5. 